\title{
Interelasi Pengeluaran Pemerintah dan Kesempatan Kerja Terhadap Pertumbuhan Ekonomi dan Kemiskinan di Provinsi Kalimantan Tengah Jurnal Ecces
}

\author{
Andi Lopa Ginting ${ }^{1}$ \\ Sondang Nauly Hasibuan ${ }^{2}$ \\ ${ }^{1}$ Program Studi Ekonomi Pembangunan \\ Fakultas Ekonomi Universitas Terbuka \\ Jalan Cabe Raya, Pondok Cabe, Pamulang, Pd. Cabe Udik, \\ Kec. Pamulang, Kota Tangerang Selatan, Banten 15418 \\ Andi.lopaginting@ecampus.ut.ac.id \\ ${ }^{2}$ Program Studi IImu Ekonomi \\ Universitas Palangka Raya \\ Jl. Yos Sudarso, Palangka, Kec. Jekan Raya, \\ Kota Palangka Raya, Kalimantan Tengah 74874 \\ Uly22hsb@gmail.com
}

\section{Abstrak: Interelasi Pengeluaran Pemerintah Dan Kesempatan Kerja Terhadap Pertumbuhan Ekonomi Dan Kemiskinan di Provinsi Kalimantan Tengah}

Permasalahan mendasar tenaga kerja Kalimantan Tengah dirumuskan sebagai penduduk usia kerja yang didominasi oleh tenaga kerja dengan kompetensi dan etos kerja rendah, produktivitas rendah sehingga menerima upah rendah, perlakuan tidak sejajar dalam hubungan industrial yang pada akhirnya menyebabkan kesejahteraan dan pekerja rendah maka dari Penelitian ini bertujuan untuk interelasi pengeluaran pemerintah dan kesempatan kerja terhadap pertumbuhan ekonomi dan kemiskinan di Provinsi Kalimantan Tengah. Metode penelitian adalah kuantitatif dengan menggunakan data sekunder time series tahun 2010-2016. Data dianalisis menggunakan path analisis. Hasil penelitian menemukan pengeluaran pemerintah berpengaruh signifikan terhadap pertumbuhan ekonomi di Provinsi Kalimantan Tengah, sehingga Prob ( 0,001 ). Pengeluaran pemerintah tidal berpengaruh signifikan terhadap kemiskinan di Provinsi Kalimantan Tengah, sehingga Prob $(0,008)$. Kesempatan kerja berpengaruh signifikan terhadap pertumbuhan ekonomi di Provinsi Kalimantan Tengah, sehingga Prob $(0,002)$. Kesempatan kerja berpengaruh signifikan terhadap kemiskinan di Provinsi Kalimantan Tengah, sehingga Prob $(0,004)$. Pertumbuhan ekonomi berpengaruh signifikan terhadap tingkat kemiskinan di Provinsi Kalimantan Tengah, sehingga Prob $(0,001)$. Pengeluaran pemerintah tidal berpengaruh signifikan terhadap tingkat kemiskinan melalui pertumbuhan ekonomi di Provinsi Kalimantan Tengah, sehingga Prob (-0.724). Kesempatan kerja berpengaruh signifikan terhadap tingkat kemiskinan melalui mediasi pertumbuhan ekonomi di Provinsi Kalimantan Tengah, sehingga Prob (1.198). Pemerintah diharapkan lebih banyak melakukan investasi yang memberikan 
manfaat pada perekonomian masyarakat secara umum seperti pembangunan infrastruktur perekonomian. Kesempatan kerja yang semakin baik berakibat pada semakin rendahnya angka kemiskinan pada masyarakat di Provinsi Kalimantan Tengah, sehingga perlu adanya peningkatan investasi baik dari pemerintah maupun swasta untuk membuka lapangan pekerjaan yang dapat meningkatkan penyerapan tenga kerja masyarakat di Provinsi Kalimantan Tengah.

Kata kunci: Pengeluaran Pemerintah, Kesempatan Kerja, Pertumbuhan Ekonomi dan Kemiskinan.

\section{Abstract: Interrelation of Government Expenditures and Job Opportunities on Economic Growth and Poverty in Central Kalimantan Province.}

The basic problems of the workforce of Central Kalimantan are formulated as working age population which is dominated by workers with low competence and work ethic, low productivity so that they receive low wages, misaligned treatment in industrial relations which in turn causes low welfare and workers hence fromThis study aims to interrelation of government spending and employment opportunities on economic growth and poverty in Central Kalimantan Province. The research method is quantitative by using secondary time series data from 2010-2016. Data is analyzed using path analysis. The results found that government expenditure had a significant effect on economic growth in Central Kalimantan Province, so Prob (0.001). Government expenditure does not have a significant effect on poverty in Central Kalimantan Province, so the Prob (0.008). Job opportunities have a significant effect on economic growth in Central Kalimantan Province, so the Prob (0.002). Job opportunities have a significant effect on poverty in Central Kalimantan Province, so the Prob (0.004). Economic growth has a significant effect on the level of poverty in Central Kalimantan Province, so the Prob (0.001). Government expenditure does not have a significant effect on poverty levels through economic growth in Central Kalimantan Province, so Prob (-0.724). Job opportunities have a significant effect on poverty levels through mediating economic growth in Central Kalimantan Province, so Prob $(1,198)$. The government is expected to make more investments that benefit the economy of the community in general such as economic infrastructure development. Improved employment opportunities result in lower poverty rates in the community in Central Kalimantan Province, so there is a need for increased investment from both the government and private sector to open up employment opportunities that can increase the absorption of community employment in Central Kalimantan Province.

Keywords: Government Expenditures, Job Opportunities, Economic Growth and Poverty.

\section{PENDAHULUAN / INTRODUCTION}

Pembangunan daerah merupakan bagian integral dari pembangunan nasional yang dilaksanakan berdasarkan prinsip otonomi daerah dan pengaturan sumberdaya nasional, yang memberikan kesempatan bagi peningkatan demokrasi dan kinerja daerah, untuk meningkatkan kesejahteraan masyarakat menuju masyarakat madani yang bebas kolusi, 
korupsi dan nepotisme. Penyelenggaraan pemerintah daerah sebagai sub sistem negara dimaksudkan untuk meningkatkan daya guna dan hasil guna peneyelenggaraan pemerintahan dan pelayanan masyarakat. Sebagai daerah otonom, Kabupaten/Kota untuk bertindak sebagai "motor" sedangkan pemerintah provinsi sebagai koordinator mempunyai kewenangan dan tanggung jawab menyelenggarakan kepentingan masyarakat berdasarkan prinsip-prinsip keterbukaan, partisipasi masyarakat dan pertanggungjawaban kepada masyarakat.

Secara umum perencanaan pembangunan adalah Cara atau teknik untuk mencapai tujuan pembangunan secara tepat, terarah, dan efisien sesuai dengan kondisi negara atau daerah bersangkutan. Karena itu perencanaan pembangunan hendaklah bersifat implementif (dapat dilaksanakan) dan aplikatif dapat diterapkan (Sjafrizal, 2009).

Kegiatan perencanaan pembangunan pada dasarnya merupakan kegiatan riset atau penelitian, karena proses pelaksanaannya akan banyak menggunakan metode-metode riset, mulai dari teknik pengumpulan data, analisis data, hingga studi lapangan/kelayakan dalam rangka mendapatkan data-data yang akurat, baik yang dilakukan secara konseptual maupun dokumentasi maupun eksperimental.

Mangkoesoebroto (1998), pengeluaran pemerintah mencerminkan kebijakan pemerintah. Apabila pemerintah telah menetapkan suatu kebijakan untuk membeli barang dan jasa, pengeluaran pemerintah mencerminkan biaya yang harus dikeluarkan oleh pemerintah untuk melaksanakan kebijakan tersebut. Teori mengenai pengeluaran pemerintah dapat digolongkan menjadi dua bagian, yaitu teori makro dan teori mikro. Dalam penelitian ini mengedepankan teori dari sisi makro. Teori makro mengenai perkembangan pengeluaran pemerintah dikemukakan oleh para ahli ekonomi dan dapat digolongkan ke dalam tiga golongan, yaitu model pembangunan tentang perkembangan pengeluaran pemerintah, hukum Wagner mengenai perkembangan aktivitas pemerintah, teori Peacock dan Wiseman.

Sejak tahun 2007, struktur belanja pemerintah daerah mengalami perubahan dari belanja publik dan aparatur menjadi belanja langsung dan tidak langsung. Perbedaan antara belanja langsung dan tidak langsung, terletak pada kaitan anggaran belanja dengan pelaksanaan program. Selama tahun 2011-2015 Pemerintah Daerah Provinsi Kalimantan Tengah telah meningkatkan belanja daerahnya tiap tahunnya. Belanja Daerah tersebut terdiri dari belanja langsung dan belanja tidak langsung terlihat pada tabel diatas. 
Andi, Sondang. Interelasi Pengeluaran Pemerintah ...

Suatu daerah sebagai area (wilayah) pembangunan dimana terbentuk konsep perencanaan pembagunan daerah dapat dinyatakan bahwa perencanaan pembangunan daerah adalah suatu proses perencanaan yang dimaksudkan untuk melakukan perubahan menuju arah yang lebih baik bagi suatu komunitas masyarakat, pemerintah dan lingkungannya dalam wilayah/daerah tertentu dengan memanfaatkan atau mendayagunakan berbagai sumber daya yang ada dan harus memilki orientasi yang bersifat menyeluruh, lengkap, tetapi tetap berpegang pada azas prioritas.

Perencanaan Pembangunan Daerah (PPD) akan membentuk tiga hal pokok yang meliputi: perencanaan komunitas, menyangkut suatu area (daerah), dan sumber daya yang ada di dalamya. Pentingnya orientasi holistik dalam perencanaan pembangunan daerah, karena dengan tingkat kompleksitas yang besar tidak mungkin kita mengabaikan masalahmasalah yang muncul sebagai tuntutan kebutuhan sosial yang tak terelakkan. Tetapi dipihak lain adanya keterbatasan sumberdaya yang dimiliki tidak memungkinkan pula untuk melakukan proses pembangunan yang langsung menyentuh atau mengatasi seluruh permasalahan dan tuntutan secara sekaligus. Dalam hal inilah penentuan prioritas perlu dilakukan, yang dalam prakteknya dilakukan melalui proses perencanaan.

Pertumbuhan ekonomi di Provinsi Kalimantan Tengah sebagai salah satu indikator keberhasilan pembangunan yang diukur dengan Produk Domestik Regional Bruto (PDRB) selama lima tahun (2011-2015) mengalami fluktuasi, pertumbuhan ekonomi tertinggi terjadi pada tahun 2013 sebesar 7,38 persen dan terendah pada tahun 2014 sebesar 6,21 persen. Proses pembangunan ekonomi daerah telah berhasil menciptakan laju pertumbuhan ratarata sebesar 6,89 persen per tahun di provinsi kalimantan tengah.

\section{TINJAUAN TEORITIK / LITERATURE REVIEW}

\section{Pertumbuhan Ekonomi}

Pertumbuhan ekonomi tidak bisa lepas dari modal atau tenaga kerja dan teknologi. Penyediaan sumber daya modal sangat diperlukan dalam pelaksanaan pembangunan. Sumber dana ini diwujudkan dalam bentuk penanaman modal (Investasi). Hal ini sangat diperlukan untuk menunjang pertumbuhan ekonomi, maupun kesempatan kerja. Dana investasi dapat diperoleh dari pemerintah, masyarakat (swasta), pinjaman luar negeri serta investasi swasta asing (Sukirno, 2002).

Pertumbuhan ekonomi merupakan salah satu indikator dari kemajuan ekonomi suatu 
negara. Menurut Kuznets dalam Sukirno (2004), Boediono (1999) dan Todaro (2003) pertumbuhan ekonomi adalah kenaikan kapasitas dalam jangka panjang dari negara yang bersangkutan, untuk menyediakan berbagai barang ekonomi kepada penduduknya. Menurut ahli - ahli ekonomi klasik ada empat faktor yang mempengaruhi pertumbuhan ekonomi yaitu jumlah penduduk, jumlah stok barang dan modal, luas tanah dan kekayaan alam serta tingkat teknologi yang digunakan. Pertumbuhan penduduk terkait dengan pertumbuhan ekonomi yang memandang sebagai faktor produksi, peningkatan jumlah penduduk akan meningkatkan jumlah angkatan kerja (labour force). Semakin banyak angkatan kerja (tenaga kerja) semakin meningkat tenaga produktif, sehingga akan meningkatkan produksi.

Namun hal itu berbeda dengan pandangan Solow dalam Suparmoko (2004), Nopirin (1999), Suryahadi (2006) dan Sumodiningrat (1996) bahwa model pertumbuhan ekonomi neo klasik, menegaskan bahwa pertumbuhan ekonomi akan tercapai jika ada pertumbuhan output. Pertumbuhan output terjadi jika dua faktor input, yakni modal dan tenaga kerja dikombinasikan, sedangkan faktor teknologi dianggap konstan (tidak berubah).

Pengertian Pengeluaran pemerintah, yaitu merupakan alokasi anggaran yang disusun dalam anggaran pendapatan dan belanja Negara (APBN) atau Anggaran pendapatan dan belanja daerah (APBD). Dimana Setiap tahunnya ke berbagai sektor atau bidang dengan tujuan untuk mensejahtrakan rakyat/masyarakat melalui bermacammacam program yang telah dibuat. Pengeluaran pemerintah berperan untuk mempertemukan permintaan masyarakat dengan penyediaan sarana dan prasarana yang tidak dapat dipenuhi oleh swasta.

Hal itu sejalan dengan gagasan Keynes dalam Suparmoko (2004), Kim (1997) dan Miller (1997) bahwa pengeluaran pemerintah dapat meningkatkan kesempatan kerja, dimana dapat dijelaskan dari sudut pandang, yaitu teori Keynes menyanggah teori klasik. Teori klasik mengemukakan pandangan mereka mengenai kesempatan kerja, yaitu bahwa tingkat output dan harga keseimbangan hanya bisa dicapai kalau perekonomian berada pada tingkat kesempatan kerja penuh (full employment). Sementara, bagi Keynesian keseimbangan dengan tingkat kesempatan kerja penuh (equilibrium with full employment) tidak akan bisa dicapai melalui mekanisme pasar bebas semata, mesti didorong dengan pengeluaran pemerintah . Jadi, adanya mekanisme pasar yang bekerja secara bebas dengan campur tangan pemerintah melalui pengeluaran pemerintah, misalnya dengan 
Andi, Sondang. Interelasi Pengeluaran Pemerintah ...

pembangunan infrastruktur, dapat menstimulan masuknya investasi dan meningkatkan kesempatan kerja.

\section{Kesempatan Kerja}

Menurut Keynes dalam Todaro (2006), bahwa dalam jangka pendek output nasional dan kesempatan kerja terutama ditentukan oleh permintaan agregat. Kaum Keynesian yakin bahwa kebijakan moneter maupun kebijakan fiskal harus digunakan untuk mengatasi pengangguran dan menurunkan laju inflasi. Konsep-konsep Keynesian menunjukkan bahwa peranan pemerintah sangat besar dalam menciptakan pertumbuhan ekonomi. Perekonomian pasar sepertinya sulit untuk menjamin ketersediaan barang yang dibutuhkan masyarakat dan bahkan sering menimbulkan instability, inequity, dan inefisiensi. Pengeluaran pemerintah daerah dalam hal ini dinyatakan dalam pengeluaran pembangunan dan pengeluaran rutin yang dapat berpengaruh terhadap pertumbuhan ekonomi. Pengeluaran pembangunan tersebut digunakan untuk memberdayakan berbagai sumber ekonomi untuk mendorong pemerataan dan peningkatan pendapatan perkapita. Pengeluaran pembangunan juga merupakan salah satu input produksi yang dapat menghasilkan output.

Sedangkan menurut Todaro (2003), Kifli (2007) dan Jamco (2008) pertumbuhan penduduk dan pertumbuhan angkatan kerja (AK) secara tradisional dianggap sebagai salah satu faktor positif yang memacu pertumbuhan ekonomi. Jumlah tenaga kerja yang lebih besar berarti akan menambah tingkat produksi, sedangkan pertumbuhan penduduk yang lebih besar berarti ukuran pasar domestiknya lebih besar. Meski demikian hal tersebut masih dipertanyakan apakah benar laju pertumbuhan penduduk yang cepat benar- benar akan memberikan dampak positif atau negatif dari pembangunan ekonominya.

Jongwanich (2007), Iradian (2005), Syaifuddin (2007) dan Sukirno (2002) dengan adanya pertumbuhan ekonomi berarti terdapat peningkatan produksi sehingga menambah lapangan pekerjaan yang pada akhirnya akan mengurangi kemiskinan. Dengan demikian, pertumbuhan ekonomi merupakan syarat keharusan (necessary condition) bagi penciptaan kesempagtan kerja dan pengurangan kemiskinan. Adapun syarat kecukupannya (sufficient condition) ialah bahwa pertumbuhan tersebut efektif dalam mengurangi jumlah pengangguran. Artinya, pertumbuhan tersebut hendaknya menyebar disetiap golongan pendapatan, termasuk golongan penduduk miskin (growth with equity). Selain itu, pertumbuhan pada sektor jasa di pedesaan menurunkan kemiskinan disemua sektor dan lokasi. Namun, pertumbuhan jasa di perkotaan memberikan nilai elastisitas kemiskinan yang 
tinggi dari semua sektor, kecuali pertanian perkotaan. Selain itu pertumbuhan pertanian dipedesaan, memberikan dampak yang besar terhadap penurunan kemiskinan disektor pertanian pedesaan, yang merupakan kontributor terbesar kemiskinan.

Hal itu juga cukup berbeda dengan gagasan Romer (1993) yang berhaluan neokeynesian bahwa pemikiran dalam kelompok Keynesian baru sangat beragam termasuk di dalamnya Mankiw, Summers, Stanley Fisher, Phelps, Akerlof, Yellen dan tiga nama yang telah disebutkan dalam Pendahuluan. Mankiw merupakan salah satu tokok yang paling banyak kontribusinya dalam pengembangan teori maupun dalam mengumpulkan artikel yang berhubungan dengan Keynesian Baru. Perhatian utama dalam Keynesian Baru adalah mencari model yang kuat dan meyakinkan untuk menjelaskan adanya kekakuan upah dan harga dengan berlandaskan pada memaksimalkan perilaku dan ekspektasi rasional. Disamping itu, Keynesian Baru juga menaruh perhatian pada penelitan tentang proses penyesuaian harga yang terjadi di perusahaan. Sampai saat ini para ekonom belum mempunyai kesatuan pendapat tentang kebijakan perusahaan dalam hal penyesuaian harga. Kelompok ini juga tidak sepenuhnya menolak pandangan Klasik Baru. Walaupun demikian Keynesian Baru tetap memberikan sokongan kepada pandangan Keynes antara lain, 1). Dalam perekonomian, adanya pengangguran yang tidak suka rela selalu berlaku, 2). Pemerintah perlu secara aktif menjalankan kebijakan untuk mengatasi masalah pengangguran dan atau inflasi dan mewujudkan kegiatan pada kesempatan kerja penuh. Dalam hal ini Keynesian Baru berkeyakinan bahwa dalam jangka panjang ekonomi pasar masih tidak akan mampu dengan sendirinya menciptakan kesempatan kerja penuh, sehingga tetap dibutuhkan adanya kebijakan pemerintah. Kebijakan pemerintah yang dimaksudkan di sini adalah yang bersifat untuk mengurangi terjadinya ketidaksempurnaan pasar.

\section{METODE PENELITIAN / METHODS}

Ruang lingkup penelitian ini adalah pengeluaran pemerintah dan angkatan kerja pada 13 kabupaten dan 1 Kota di Provinsi Kalimantan Tengah tahun 2010-2016, Pertumbuhan ekonomi atas dasar harga konstan dan Kemiskinan pada 13 Kabupaten dan 1 Kota di Provinsi Kalimantan Tengah tahun 2010-2016. 
Andi, Sondang. Interelasi Pengeluaran Pemerintah ...

\section{Variabel Penelitian}

Kuncoro (2003), Widarjono (2007), Arsyad (2008), Gujarati (1999) definisi operasional variabel adalah pengertian variabel (yang diungkap dalam definisi konsep) tersebut , secara operasional, secara praktik, secara nyata dalam lingkup obyek penelitian/obyek yang diteliti. Variabel yang digunakan dalam penelitian ini adalah variabel bebas dan variabel terikat.

\section{a. Variabel Bebas (Independent Variable)}

Variabel bebas adalah variabel yang mempengaruhi, yang menyebabkan timbulnya atau berubahnya variabel terikat. Variabel bebas yang digunakan dalam penelitian ini adalah locus of control dan kepribadian.

\section{b. Variabel Terikat (Dependent Variable)}

Variabel terikat adalah variabel yang dipengaruhi karena adanya variabel bebas.Variabel terikat yang digunakan dalam penelitian ini adalah kinerja. Definisi operasional variable penelitian merupakan penjelasan dari masing-masing variabel yang digunakan dalam penelitian terhadap indikator-indikator yang membentuknya. Definisi operasional variabel dalam penelitian ini memiliki batasan sebagai berikut :

1) Pertumbuhan Ekonomi $\left(\mathrm{Y}_{2}\right)$ adalah pertambahan laju pertumbuhan Produk Domestik Regional Bruto (PDRB) di Provinsi Kalimantan Tengah dinyatakan dalam persen.

2) Pengeluaran Pemerintah $\left(X_{1}\right)$ adalah Pengeluaran Pemerintah di Provinsi Kalimantan Tengah dinyatakan dalam Persen.

3) kesempatan Kerja $\left(X_{2}\right)$ adalah orang yang bekerja di Provinsi Kalimantan Tengah dinyatakan dalam Persen.

4) Kemiskinan $\left(Y_{1}\right)$ adalah Jumlah orang yang tidak mampu memenuhi kebutuhannya yang dinyatakan dalam persen.

Penelitian ini terbatas pada kegiatan menganalisis interelasi Pengeluaran Pemerintah dan Kesempatan Kerja terhadap pertumbuhan ekonomi serta Kemiskinan di Provinsi Kalimantan Tengah periode tahun 2010 sampai dengan 2016. 


\section{HASIL DAN PEMBAHASAN / DISCUSSION}

Berdasarkan perhitungan secara keseluruhan interelasi pengeluaran pemerintah, kesempatan kerja dan pertumbuhan ekonomi terhadap kemiskinan di Provinsi Kalimantan Tengah. Pengujian hipotesis pada penelitian ini menggunakan analisis jalur (path analysis). Sementara perhitungan secara statistik pada penelitian ini menggunakan program SPSS 22.0 for windows. Pengujian hipotesi diuji melalui tiga tahapan, yaitu :

\section{1). Uji Koefisien Determinasi $\left(\mathbf{R}^{2}\right)$}

Uji $\mathrm{R}^{2}$ dilakukan untuk menguji kemampuan variabel eksogen mempengaruhi dan menjelaskan variabel endogen. Nilai $R^{2}$ yaitu $0<R^{2}<1$ (Sandjojo, 2011).

\section{2). Uji t}

Uji t digunakan untuk menguji apakah pertanyaan hipotesis benar. Uji statistik t pada dasarnya menunjukkan seberapa jauh pengaruh suatu variabel penjelas secara individual dalam menerangkan variabel terikat. Untuk pengujian uji $t$, dalam penelitian ini dilihat dari probalitas/signifikasi $=$ à 0,05 .

Ho : ditolak, jika probabilitas $\mathrm{t}<$ á 0,05 ;

Ho : diterima, jika probabilitas $\mathrm{t}>$ à 0,05

\section{3). Uji F}

Uji F-statistik ini adalah pengujian yang bertujuan untuk mengetahui pengaruh antara seluruh variabel independen secara bersama-sama terhadap variabel dependen. Untuk pengujian dilihat melalui probalitas sebagai berikut:

a. Ho : ditolak, jika probabilitas $\mathrm{F}<$ à 0,05

b. Ho : diterima, jika probabilitas $F>$ à 0,05

Interelasi Pengeluaran pemerintah, kesempatan kerja dan pertumbuhan ekonomi terhadap kemiskinan. 
Andi, Sondang. Interelasi Pengeluaran Pemerintah ...

Tabel 1 Koefisien Analisis Jalur

\begin{tabular}{lcccc}
\hline \multicolumn{1}{c}{ Hubungan Variabel } & Koefisien & t hitung & P & Ket \\
\hline $\begin{array}{l}\text { Pengeluaran Pemerintah } \rightarrow \text { Pertumbuhan } \\
\text { Ekonomi }\end{array}$ & 0,301 & 1,039 & 0,001 & Sig \\
\hline Kesempatan Kerja $\rightarrow$ Pertumbuhan Ekonomi & 0,002 & 3,202 & 0,002 & Sig \\
\hline Pengeluaran Pemerintah $\rightarrow$ Kemiskinan & 0,025 & 0,696 & 0,008 & Sig \\
\hline Kesempatan Kerja $\rightarrow$ Kemiskinan & 0,072 & $-2,043$ & 0,004 & Sig \\
\hline Pertumbuhan Ekonomi $\rightarrow$ Kemiskinan & $-0,631$ & $-3,578$ & 0,001 & Sig \\
$\begin{array}{l}\text { Pengeluaran Pemerintah } \rightarrow>\text { Pertumbuhan } \\
\text { Ekonomi } \rightarrow \text { Kemiskinan }\end{array}$ & -0.013 & -0.724 & 0.018 & Sig \\
Kesempatan Kerja $\rightarrow$ Pertumbuhan Ekonomi $\rightarrow$ & $-0,038$ & 1.918 & 0.020 & Sig \\
Kemiskinan & & & & \\
\hline
\end{tabular}

Gambar 1

Interelasi Pengeluaran Pemerintah Dan Kesempatan Kerja Terhadap Pertumbuhan Ekonomi Serta Kemiskinan di Provinsi Kalimantan Tengah

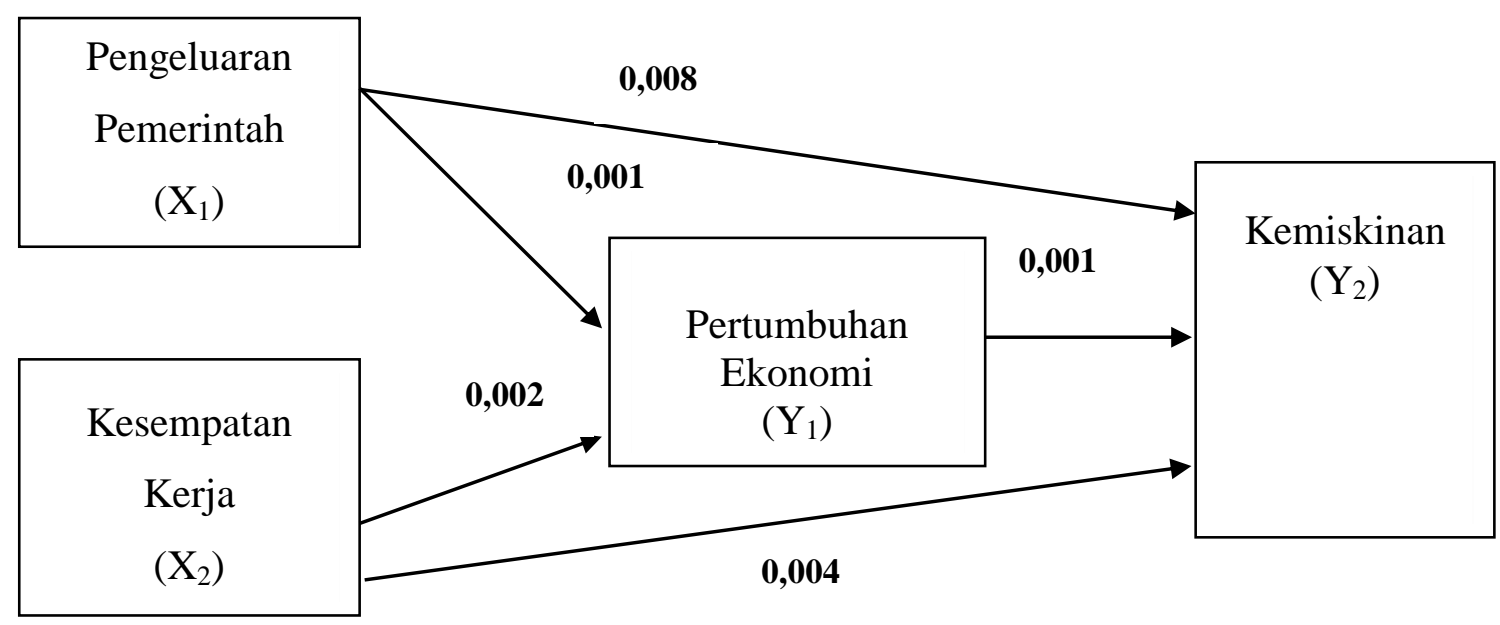

Persamaan dalam penelitian ini, mengestimasi pengaruh pengeluaran pemerintah dan kesempatan kerja terhadap tingkat kemiskinan melalui pertumbuhan ekonomi di Provinsi Kalimantan Tengah. Berdasarkan hasil analisis jalur untuk interelasi pengeluaran pemerintah dan kesempatan kerja terhadap tingkat kemiskinan melalui pertumbuhan ekonomi di Provinsi Kalimantan Tengah dengan gambar dan diuji dengan menggunakan Sobel Test dengan rumus sebagai berikut: 


$$
\mathbf{S}_{\mathrm{ab}}=\mathrm{b}^{2} \mathrm{Sa} \mathrm{a}^{2}+\mathrm{a}^{2} \mathrm{~S} \mathrm{~b}^{2}+\mathrm{Sa}^{2} \mathrm{~b}^{2}
$$

Keterangan:

a : Koefisien direct effect $X$ terhadap $Y$

b $\quad$ : Koefisien direct effect $\mathrm{Y}$ terhadap $\mathrm{Z}$

Sa $\quad$ : Standar error dari koefisien a

Sb : Standar error dari koefisien b

Berdasarkan hasil analisis jalur (path analysis) untuk pengaruh pengeluaran pemerintah dan kesempatan kerja terhadap kemiskinan melalui pertumbuhan ekonomi di Provinsi Kalimantan Tengah diperoleh hasil perhitungan sebagai berikut:

1. Interelasi Pengeluaran Pemerintah terhadap Kemiskinan melalui Pertumbuhan Ekonomi

Perhitungan Sobel Test untuk pengaruh pengeluaran pemerintah terhadap kemiskinan melalui mediasi pertumbuhan ekonomi adalah sebagai berikut:

$$
\begin{aligned}
S_{a b} & =b^{2} S^{2}+a^{2} S^{2}+S^{2} b^{2} \\
& =-0.631^{2} \times 0.020+0.021^{2} \times 0.176^{2}+0.020^{2} X-0.631^{2} \\
& =0.002+0.00001-0.0002 \\
& =0.0003 \\
& =0.018 \\
Z & =a b / S a b \\
& =-0.013 / 0.018 \\
& =-0.724
\end{aligned}
$$

Berdasarkan hasil Sobel Test untuk interelasi pengeluaran pemerintah terhadap kemiskinan melalui mediasi pertumbuhan ekonomi diperoleh nilai $Z=-0.724<1.96$, sehingga $\mathrm{H}_{0}$ diterima, artinya pengeluaran pemerintah berpengaruh signifikan terhadap kemiskinan melalui mediasi pertumbuhan ekonomi, sehingga ada kecenderungan bahwa pengeluaran pemerintah berpengaruh terhadap kemiskinan.

2. Interelasi Kesempatan Kerja terhadap Kemiskinan melalui Pertumbuhan Ekonomi

Perhitungan Sobel Test untuk interelasi kesempatan kerja terhadap kemiskinan melalui mediasi pertumbuhan ekonomi adalah sebagai berikut:

$$
\begin{aligned}
\mathrm{S}_{\mathrm{ab}} & =\mathrm{b}^{2} \mathrm{Sa}^{2}+\mathrm{a}^{2} \mathrm{Sb}^{2}+\mathrm{Sa}^{2} \mathrm{~b}^{2} \\
& =-0.631^{2} \times 0.020^{2}+0.021^{2} \times 0.176^{2}+0.020^{2} \mathrm{x}-0.631^{2} \\
& =0.0001+0.00012-0.0001 \\
& =0.0004
\end{aligned}
$$




$$
\begin{aligned}
& =0.020 \\
Z & =a b / \text { Sab } \\
& =-0.038 / 0.020 \\
& =1.918
\end{aligned}
$$

Berdasarkan hasil Sobel Test untuk interelasi pengeluaran perkapita terhadap kesejahteraan masyarakat melalui pertumbuhan ekonomi diperoleh nilai $Z=1.918>1.66$, sehingga $\mathrm{H}_{0}$ ditolak, artinya kesempatan kerja berpengaruh signifikan terhadap kemiskinan melalui mediasi pertumbuhan ekonomi pada taraf signifikan $10 \%$. Hasil penelitian ini memberikan gambaran tentang hubungan antara pengeluaran pemerintah, kesempatan kerja, pertumbuhan ekonomi dan tingkat kemiskinan di Provinsi Kalimantan Tengah, adapun implikasi hasil penelitian ini adalah sebagai berikut.

\section{KESIMPULAN / CONCLUSION}

Berdasarkan hasil pengujian dan pembahasan diatas dapat disimpulkan bahwa pengeluaran pemerintah tidak berpengaruh positif dan signifikan terhadap pertumbuhan ekonomi dan kemiskinan di Provinsi Kalimantan Tengah. Namun, kesempatan kerja dan pertumbuhan ekonomi berpengaruh positif dan signifikan terhadap kemiskinan dan di Provinsi Kalimantan Tengah. Kesempatan kerja dan pertumbuhan ekonomi meningkat, maka akan menurunkan angka kemiskinan dan meningkatkan angka angkatan kerja pada Provinsi Kalimantan Tengah demikian sebaliknya.

Jika melihat hasil penelitian dari pengeluaran pemerintah, dimana hasil yang ditunjukan signifikan dalam mengurangi kemiskinan. Hal ini tentunya tidak terlepas dari proses investasi pemerintah dalam membangun perekonomian masyarakat, sehingga pemerintah diharapkan lebih banyak melakukan investasi yang memberikan manfaat pada perekonomian masyarakat secara umum seperti pembangunan infrastruktur perekonomian. Kesempatan kerja yang semakin baik berakibat pada semakin rendahnya angka kemiskinan pada masyarakat di Provinsi Kalimantan Tengah, sehingga perlu adanya peningkatan investasi baik dari pemerintah maupun swasta untuk membuka lapangan pekerjaan yang dapat meningkatkan penyerapan tenga kerja masyarakat di Provinsi Kalimantan Tengah. Kemiskinan di Provinsi Kalimantan Tengah berhasil diturunkan dari tahun ke tahun, sehingga perlu upaya pemerintah untuk melakukan kinerjanya secara lebih optimal dalam rangka 
menciptakan lapangan kerja serta meningkatan perekonomian sehingga kemiskinan dapat semakin ditekan.

\section{DAFTAR PUSTAKA / REFERENCES}

Arsyad, Lincolin dan Soeratno. 2008. Metode Penelitian Ekonomi dan Bisnis, Penerbit BPFE, Yogyakarta.

Boediono. 1999. Teori Pertumbuhan Ekonomi, Seri Sinopsis, Edisi Pertama, Cetakan Keenam, BPFE, Yogyakarta.

Gujarati,D. 1999. Essential of Econometrics., McGraw-Hill.Inc. Second Edition, London.

Iradian, Garbis. 2005. Inequality, Poverty and Growth : Cross-Country Evidence. IMF Working Paper.

Jamco, Muhammad Taher. 2008. Faktor-faktor yang berpengaruh terhadap tingkat kemiskinan di Kabupaten Maluku Tenggara, 2002-2006. Tesis S2, Sekolah Pascasarjana UGM. Yogyakarta.

Jongwanich, Juthathip. 2007. Worker's Remittances, Economic Growth and Poverty in Developing Asia and Pacific Countries, United Nation Economic and Social Commission for the Asia and Pacifics Countries (UNESCAP) Working Paper.

Kifli, Sofia. 2007.Analisis faktor-faktor yang mempengaruhi Kemiskinan di Propinsi Lampung, Tahun 2000-2005. Tesis S2, Sekolah Pasca Sarjana UGM.

Kuncoro,Mudrajad. 2003. Metode Riset untuk Bisnis dan Ekonomi, Penerbit Erlangga, Jakarta.

Kim, Sung Tai. 1997. The Role of Local Public Sectors in Regional Growth in Korea. Asian Economic Journal, Vol.11 No.21, 155-168.

Mangkoesoebroto, Guritno. 1998. Ekonomi Publik, BPFE, Edisi 3, Yogyakarta. 
Andi, Sondang. Interelasi Pengeluaran Pemerintah ...

Miller, Stephen. M and Frank,Russek S. 1997. Fiscal Structure and Economic Growth at The State and Local Level. Public Finance Rivew, Vol.25 No.3, 213-237.

Nopirin. 1999. Pengantar Ilmu Ekonomi Makro \& Mikro, BPFE. Yogyakarta.

Raminta. 2003. Dampak Proyek Penanggulangan Kemiskinan Perkotaan (P2KP) Dalam Meningkatkan Kesejahteraan Masyarakat, 1999-2000, Studi Kasus di Desa Margoagung, Kecamatan Seyegan, Kabupaten Slema. Tesis S2, Program MEP UGM.

Republik Indonesia. 1999. Undang-undang Otonomi Daerah, Kuraiko Pratama, Bandung.

Romer, D. 1993. The New Keynesian Synthesis, Journal of Economic Perspectives, Vol. 7, No. 1 , Winter.

Sumodiningrat,Gunawan. 1996. Pemberdayaan Masyarakat, Pena Kencana Nusadwipa. Jakarta.

Suryahadi, Asep, Daniel Suryadarma dan Sudarno Sumarto. 2006. Economic Growth and Poverty Reduction : The Effect Of Location and Sectoral Components Of Growth", Working Paper, SMERU Research Institute. Jakarta.

Sukirno,S. 2004. Pengantar Makro Ekonomi. Jakarta: Jakarta Press.

Sukirno,S. 2002. Pengantar Teori Makro Ekonomi Edisi Kedua. Jakarta: Jakarta Press.

Suparmoko. 2004. Keuangan Negara dalam Teori dan Praktek, Edisi ketujuh. Yogya-karta: BPFE.

Sjafrizal and ML Jhingan. 2009. Perencanaan Pembangunan, Penerbit Erlangga, Jakarta.

Todaro, Michael P. and Smith, Stephen C. 2003. Pembangunan Ekonomi di Dunia Ketiga, Edisi Ke-8, Penerbit Erlangga, Jakarta.

Todaro, M.P. 1997. Pembangunan Ekonomi di Dunia Ketiga, Cetakan Keempat, Jakarta. 

p-ISSN: 2407-6635 e-ISSN : 2580-5570

Todaro, Michael P. and Smith, Stephen C. 2006. Pembangunan Ekonomi, Edisi Terjemahan, Edisi Kesembilan, Jilid 1, Penerbit Erlangga, Jakarta.

Widarjono, Agus. 2007. Ekonometri dan Aplikasi untuk Ekonomi dan Bisnis, Penerbit Ekonisia FE-UII, Yogyakarta. 